\title{
Value Chain Analysis of Chaya (Mayan Spinach) in Guatemala
}

\author{
Nadezda Amaya*, Stefano Padulosi, and Gennifer Meldrum \\ Bioversity International, Via dei Tre Denari, 472/a 00054 Maccarese, Rome, Italy \\ *Corresponding author; e-mail: nadezdaa@gmail.comN.Amaya@cgiar.org
}

\begin{abstract}
Chaya is a highly nutritious perennial leafy vegetable native to Mesoamerica. This drought-resistant crop has low production and consumption levels in Guatemala, but has the potential to help agriculture and food systems be more nutritious and resilient. This study analyzed the value chain of chaya in Guatemala, and identified bottlenecks and opportunities for its use-enhancement. This research, the first of its kind applied to this crop in Guatemala, combined Rapid Market Appraisal tools. Small-scale chaya production, consumption, and marketing were observed in three focal sites (Guatemala City, Petén, and Dry Corridor). It was observed that producers are not motivated to produce chaya commercially and vendors are unwilling to sell it because of low demand and profitability. One Guatemalan company identified produces nutraceutical chaya products with few sales points in the country and occasionally abroad. Low demand is a primary bottleneck in the value chain due to lack of consumer awareness, changing eating habits, limited recipes, and availability in home-gardens. There is also a reluctance to grow, consume, or sell a crop perceived as a "food of the poor." Low prices and profitability were other constraints registered. The findings can inform future interventions for enhancing the use of this crop to fight malnutrition.
\end{abstract}

Chaya es un vegetal de hoja perenne muy nutritivo originario de Mesoamérica. Este cultivo resistente a la sequía, tiene bajos niveles de producción y consumo en Guatemala, pero tiene el potencial de ayudar a que sistemas agrícolas alimentarios sean más nutritivos y resistentes. Este estudio analizó la cadena de valor de la chaya en Guatemala e identificó cuellos de botella y oportunidades para mejorar su uso. Esta investigación, la primera de su tipo aplicada a este cultivo en Guatemala, combinó herramientas de evaluación rápida de mercado. Se estudio la producción, consumo y comercialización de chaya a pequeña escala en tres sitios focales (Ciudad de Guatemala, Petén y Corredor Seco). Se observó que los productores no están motivados para producir chaya comercialmente y los vendedores no están dispuestos a venderla debido a su baja demanda y rentabilidad. Una empresa guatemalteca identificada produce productos nutracéuticos de chaya con pocos puntos de venta en el país y ocasionalmente en el extranjero. La baja demanda es un cuello de botella importante en la cadena de valor, que se debe a la falta de conocimiento del consumidor, cambios en hábitos alimenticios, pocas recetas y limitada disponibilidad en huertos familiares. También existe una renuencia a cultivar, consumir o vender un cultivo que se percibe como "alimento de pobres." Otras restricciones identificadas fueron bajos precios y rentabilidad. Los hallazgos de este estudio pueden informar futuras intervenciones para mejorar el uso de este cultivo para combatir la desnutrición.

Key Words: Food security, Income generation, Indigenous vegetable, Markets, Neglected and underutilized species, Nutrition.

Key Words: Seguridad alimentaria, generación de Ingreso, vegetales Indígenas, mercados, especies olvidadas y subutilizadas, nutrición.

\footnotetext{
${ }^{1}$ Received 20 March 2019; accepted 3 December 2019; published online 17 December 2019

Electronic supplementary material The online version of this article (https://doi.org/10.1007/s12231-01909483-y) contains supplementary material, which is available to authorized users.
}

\section{Introduction}

Chaya (Cnidoscolus aconitifolius Mill I.M. Johnst) is a nutritious leafy vegetable in the Euphorbiaceae family. This crop, also known as "Mayan spinach," has been cultivated for centuries by the Mayans as a 
staple food, typically planted in homegardens and maize fields (Booth et al. 1992; Ross-Ibarra 2003). Chaya was likely domesticated in the Yucatan peninsula, but is commonly used throughout Mesoamerica, with the highest production found in the Mexican states of Yucatan, Campeche, and Quintana Roo (Cifuentes et al. 2010). This plant has been introduced in other parts of the world in recognition of its nutritional value (e.g., Africa and Asia; Porres and Cifuentes 2014). Chaya is a perennial shrub that is well adapted to drought-prone areas, has a short growth cycle, and is relatively easy to cultivate (Kuti and Torres 1996). The plant can reach a mean height of 3-5 $\mathrm{m}$, and its leaves can be harvested year-round. It has been estimated that a plantation can reach an annual production of 3060 tons per hectare of fresh leaves (Porres and Cifuentes 2014).

Chaya is an important source of vitamins (A, C), minerals (calcium, iron, zinc, phosphorus, magnesium), protein, carbohydrates, and polyunsaturated fatty acids, of which 50\% are omega-3 type (Kumar et al. 2011; Molina-Cruz et al. 1997). Chaya leaves have high nutritional values compared to other leafy vegetables consumed in Central America (Fig. 1). For instance, $100 \mathrm{~g}$ of fresh leaves contain about four times an adult's daily vitamin $\mathrm{C}$ requirement, which is 10 times the amount found in chard (Beta vulgaris L.) and eight times that of spinach (Spinacia oleracea L.; FDA 2016; Leung and Flores 1961; Molina-Cruz and Cifuentes 2001). Owing to its dry protein content (31\% compared with $25 \%$ in common bean), chaya can help raise Guatemalans' protein intake, which is among the lowest in
Central America (Neufeld et al. 2006). Chaya is furthermore known for its role in treating various health issues, including diabetes, obesity, kidney stones (Ross-Ibarra and Molina-Cruz 2002), and gastrointestinal disorders (Kuti and Torres 1996), although more research is needed to validate its healing properties (Ferraz et al. 2018). Uncooked chaya leaves contain toxic cyanide glycosides, which differ significantly by variety (Cifuentes et al. 2010), but are destroyed with just five minutes in boiling water (González-Laredo et al. 2003).

In Guatemala, chaya is cultivated in 17 of the country's 22 departments, with the highest production in Petén, Izabal, and Alta Verapaz (Cifuentes et al. 2010). Four cultivars can be found in the country: Estrella, Mansa, Plegada, and Picuda, among which the first two are the most popular (Cifuentes et al. 2010). Chaya's potential as an economically viable and highly nutritious food source has been known for decades (Molina-Cruz et al. 1997). Nevertheless, its cultivation and consumption remain on a small scale in Guatemala and its existence and values are unknown to a large part of the population (Azurdia 2016). This situation is common to many nutritious crops around the world-referred to as neglected and underutilized species - that are important in local food traditions but are not integrated to their full potential in mainstream food and agriculture systems (Hunter et al. 2019; Padulosi et al. 2019).

Weak value chains are an important factor that limit the use of nutritious traditional crops (Baldermann et al. 2016). A value chain is a series of activities performed to bring an agricultural

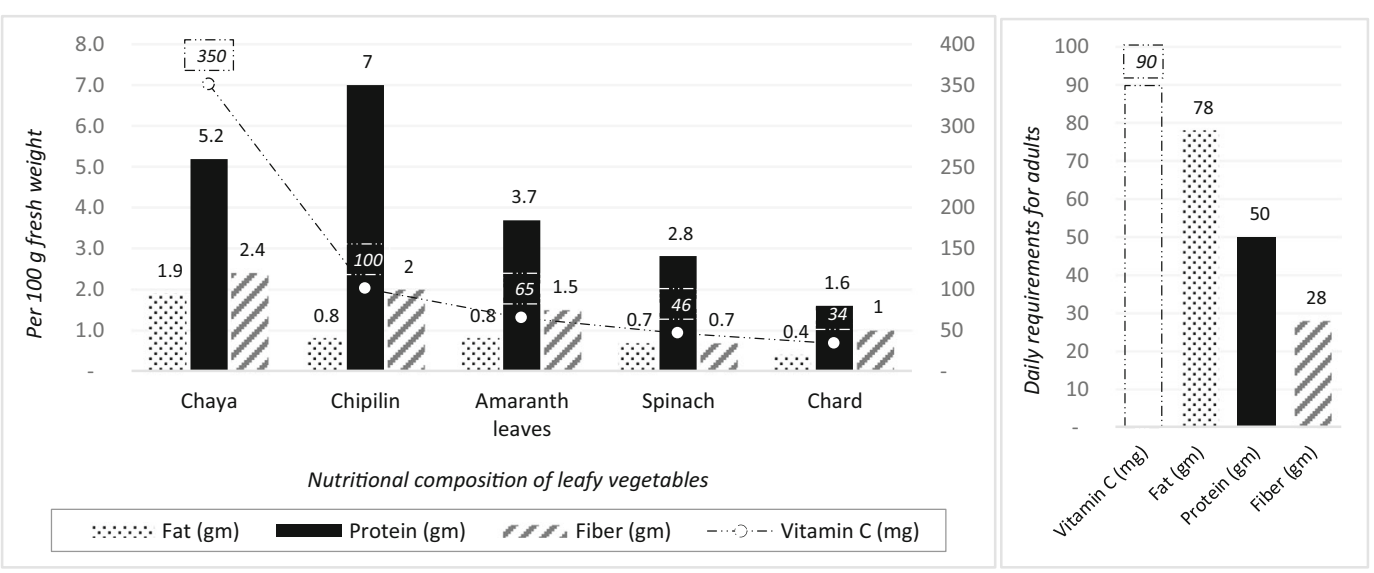

Fig. 1. Comparison of nutritional composition between chaya, similar leafy vegetables consumed in Central America, and daily requirements. Source: FDA ( 2016); Leung and Flores (1961); Molina-Cruz and Cifuentes (2001) 
product from production to consumption, with value being added at each stage (Kaplinsky and Morris 2000). Often multiple constraints are faced in the value chains of neglected and underutilized species, which undermine their competitiveness and makes them less attractive to grow, commercialize, and consume when other options are available (Padulosi et al. 2015, 2019). These bottlenecks include: (1) agronomic constraints that result in low or irregular yields; (2) commercialization constraints, such as insufficient margins, infrastructure limitations, and scant coordination among value chain actors; and (3) weak consumer demand linked to low awareness, low prestige of the crop, difficult processing, and issues related to product quality and convenience (Gruère et al. 2008; Padulosi et al. 2015). Identification of value chain bottlenecks is a key step toward identifying strategies to encourage greater use of these crops and realizing their full values (Gruère et al. 2008).

The marketing of chaya in Guatemala has not commanded considerable research attention so far, and it is rare to see its leaves on sale in local and regional markets (Azurdia 2016). The organization and obstacles in the chaya value chain have not been documented to our knowledge. This study aimed to fill this gap by providing insights on how to better leverage chaya's livelihood benefits. A Rapid Market Appraisal (RMA) method was applied to collect qualitative information from producers, traders, consumers, and other value chain actors (Ferris 2012; Holtzman 2003), which was complemented by interviews with experts, literature review, and internet searches. Variations of this approach have been applied to assess the value chains of other neglected and underutilized species in other regions (Bandula et al. 2016; Van Looy et al. 2008). We expected that multiple problems exist at different points in the value chain for chaya related to production, commercialization, and consumer demand that limit its integration into the mainstream food system. The presence of bottlenecks was assessed through qualitative analysis of information gathered in the interviews.

\section{Study Sites}

Guatemala is a Mesoamerican country rich in cultural and biological diversity, where most of the population is of indigenous descent (Grant 2015). The agricultural sector accounts for $10 \%$ of the gross domestic product, employs over $29.4 \%$ of the labor force, and uses 36\% of the country's land area, of which half is destined to grow staple grains (maize, beans, and sorghum) and commercial crops (coffee, bananas, sugar cane; FAO 2018). Smallholder and subsistence farmers represent $92 \%$ of agricultural producers, albeit cultivating as a whole only one-fifth of the land (INE 2004). Guatemala faces widespread poverty, with $54 \%$ of its population living under the poverty line and $13 \%$ in extreme poverty (UN 2017). Chronic malnutrition affects half of children under five (FAO et al. 2017) and $80 \%$ of the indigenous population (MAGA 2015).

Three sites with distinct climatic and socioeconomic conditions were selected for the value chain analysis in order to capture a range of contextual variation helpful to provide insights into the reality and opportunities for marketing chaya in Guatemala. The location of the study sites is shown in Fig. 2, and features of the sites are summarized in Table 1 and described below:

1) Guatemala City, situated in the central-south part of the country, is the largest city in Guatemala and Central America (INE 2011). It is the major market for goods and services and the most economically powerful center in Guatemala. Considering that any major commercialization of chaya in the country would likely involve the major urban centers, five markets were surveyed there: Central Mayoreo (CENMA), Palmita, Presidenta, Terminal, and Central.

2) Petén, the northernmost department, accounts for one-third of Guatemala's total area. It presents a tropical climate with a long rainy season (MAGA 2016). Tourism is one of the most important engines of its economy, along with agriculture, forestry, and fruit production (SEGEPLAN 2013). Petén was selected because the highest levels of chaya production and use in Guatemala have been documented there (Azurdia 2016). Two local markets in the municipality of Flores (San Benito and Santa Elena) were selected jointly with three communities in the municipalities of San Andres, San Jose, and Flores, which supply chaya to those markets (Narciso et al. 2013).

3) Chiquimula and Zacapa departments are located in the south-eastern part of Guatemala. They are part of the Dry Corridor, a semi-arid zone that 

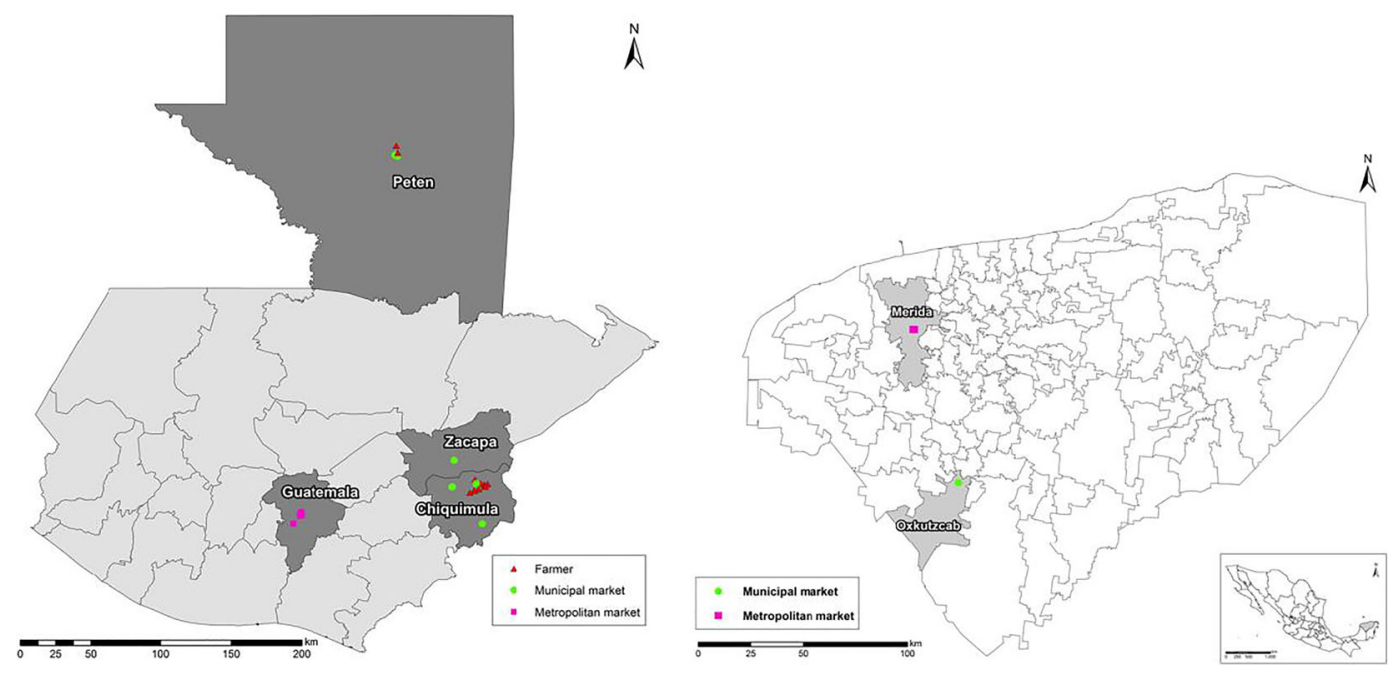

Fig. 2. Location of focal markets and producer communities included in the study

exhibits frequent periods of drought, poor soils, and low agricultural performance (SEGEPLAN $2011 \mathrm{a}, \mathrm{b})$. Nearly all the work force is engaged in agriculture, mostly in the production of staple grains and to a lesser extent fruits and vegetables, such as chaya (SEGEPLAN 2002). These departments were selected as an ideal setting for exploring the current and future prospects of chaya for nutrition and income generation as the population faces a high burden of poverty and chronic malnutrition. Four markets in Chiquimula (Central, Terminal, Esquipulas, and Jocotán) and one in Zacapa (Zacapa) were targeted, along with seven communities distributed in three municipalities (Camotán, Jocotán, and San Juan Ermita) that have important commercial flows with the chosen markets.

Moreover, to better contextualize the chaya value chain in Guatemala, the Mexican State of Yucatan was also included in the study, given the high levels of chaya cultivation documented in the region (Azurdia 2016). Two important markets in the capital city of Merida were visited (Lucas de Galvez and Casa del Pueblo), as well as one in the rural area (Oxkutzcab).

\section{Methods}

The RMA method applied in this study relied on a combination of secondary information, field observations, and primary qualitative data collected through semi-structured interviews. As there was limited information in literature about the chaya value chain, we started by interviewing knowledgeable experts from governmental institutions, NGOs, universities, and the private sector. We then surveyed leafy vegetable traders and consumers in the twelve focal markets, which are the most important, busiest, and key suppliers of products for smaller markets in their respective sites. Likewise,

Table 1. ReleVant conditions, By site. Source: IICA 2015, INE 2014, MSPAS et Al. 2017

\begin{tabular}{llllll}
\hline \hline & Guatemala City & Petén & Chiquimula & Zacapa & Merida \\
\hline Population (million) & 3.2 & 0.66 & 0.36 & 0.22 & 0.89 \\
Altitude (meters above sea level) & 1500 & $80-510$ & $160-1850$ & $130-880$ & 10 \\
Temperature ${ }^{\circ} \mathrm{C}$ & $12-25$ & $21-32$ & $27-42$ & $21-34$ & $28-38$ \\
Annual precipitation $(\mathrm{mm})$ & 250 & $1265-1800$ & $775-1115$ & $500-1500$ & 1037 \\
Poverty & $33 \%$ & $61 \%$ & $71 \%$ & $56 \%$ & $29 \%$ \\
Malnutrition & $25 \%$ & $37 \%$ & $56 \%$ & $40 \%$ & $27 \%$ \\
\hline
\end{tabular}


surveys were carried out with chaya producers in the ten communities selected in Chiquimula and Petén. The presence and level of use of chaya in restaurants, supermarkets, and health food stores were also investigated in the target sites. The steps followed for the implementation of the RMA are provided as Electronic Supplementary Material (ESM) in Appendix 1.

Respondents were selected through convenience and snowball sampling methods. Approximately 35 interviews were conducted at each stage of the chaya value chain by site (ESM, Appendix 2). In total, 186 informants were interviewed between March and November 2017, including vendors of leafy vegetables (64), consumers in local and regional markets (43), restaurants that use leafy vegetables (16), processing industry (4), chaya producers (20), and knowledgeable experts (39). Five types of semistructured interview guidelines, including open questions tailored to the specific group of actors, were applied to allow a natural flow of discussion. The information collected covered current practices for production, consumption, marketing, and processing of chaya and other leafy vegetables: stakeholders' roles, market competitiveness, product attributes, prices, trends, and incentives. All the interviews were recorded in notebooks and audio recordings, with the participants' oral consent. Interviews with producers and experts typically lasted 60$90 \mathrm{~min}$, and those with vendors and consumers 20-30 min on average. Direct observations during field visits also supported our understanding of the context and local conditions in which the chaya value chain operates.

\section{DATA ANALYSIS}

The qualitative data gathered were transcribed in Microsoft Word and systematized using Microsoft Excel. The general analysis strategy was patternmatching, which is a common approach for explanatory studies (Hyde 2000). Guiding questions were assessed regarding core processes and actors along the chaya value chain, including bottlenecks, opportunities, and the context in which it performs. First, individual case descriptions (i.e., actors interviewed) were made; then the data from each case were compared and contrasted to the other cases (cross-case analysis). This comparison was made using key words, themes, and categories (e.g., quantity, frequency, and uses) to help identify patterns among these elements and how they relate to each other, including contradictory data, which made the analysis stronger. Particular attention was paid to identifying potential reasons for the underutilization of chaya and whether this related to issues in production, commercialization, and/or consumer demand. Finally, the analyzed information was used to go beyond description of particular cases to general explanations, and to represent graphically the basic structure of the chaya value chain (ESM, Appendix 3).

\section{Results}

\section{VENDOR SURVEYS}

Based on direct observations in all the focal markets, we estimated that between 5 and $10 \%$ of the vendors were selling vegetables, of which $20-50 \%$ sold leafy vegetables. Some of these vendors were commercializing their products in established stalls and others placed their produce in small baskets on the floor, which was the case for most selling chaya. Besides Spanish, a third of the vegetable vendors interviewed in the markets also spoke Mayan languages: Cakchiquel and Quiche (Guatemala City), Kekchi (Petén), and Mam (Chiquimula). Around $80 \%$ of the informants and all those selling chaya were women, who according to respondents "understand business better than men." In Guatemala City, 22\% of the vendors interviewed knew about chaya, while all of those in Petén (100\%) and the majority in the Dry Corridor (77\%) were aware of this plant. Only 14 of the 54 respondents were selling chaya at the time of the interviews (Table 2).

Finding chaya in the focal markets was difficult and we were only able to encounter it on sale in 6 of the 12 surveyed markets: Central and Palmita in Guatemala City, San Benito and Santa Elena in Petén, and Jocotán and Central in Chiquimula. In these markets chaya was sold in bundles (Fig. 3), made by 15-25 fresh leaves tied together with string (weighing approximately $250 \mathrm{~g} / \mathrm{bundle}$ ) and in small amounts (10-15 bundles). Estrella and Mansa were the varieties sold in Guatemala City and Chiquimula, whereas Estrella was the only type found in Petén.

In Petén and Chiquimula, chaya vendors were predominantly farmers who produced the leaves in their homegardens and brought a mean $70 \%$ of their fresh production to the markets for direct sale to consumers. In other cases, vendors bought chaya directly from producers. The vendors reached the market by bus, taxi, bicycle, foot, or a combination 
TABLE 2. VeNDORS INTERVIEWED IN FOCAL MARKETS IN GUATEMALA, BY SITE

\begin{tabular}{|c|c|c|c|c|c|}
\hline \multirow[t]{2}{*}{$\overline{\text { Site }}$} & \multirow[t]{2}{*}{ Market } & \multicolumn{2}{|c|}{ Estimated \# of vendors } & \multicolumn{2}{|c|}{ \# of leafy vegetable vendors interviewed } \\
\hline & & Vegetable & Leafy vegetables & Total & Chaya vendors \\
\hline \multirow[t]{5}{*}{$<\mathrm{TB}>$ Guatemala City } & CENMA & 50 & 10 & 4 & \\
\hline & Palmita & 50 & 20 & 6 & 2 \\
\hline & Presidenta & 20 & 5 & 4 & \\
\hline & Terminal & 250 & 100 & 5 & \\
\hline & Central & 50 & 15 & 4 & 1 \\
\hline \multirow{2}{*}{ Petén } & San Benito & 25 & 10 & 4 & 3 \\
\hline & Santa Elena & 20 & 10 & 5 & 4 \\
\hline \multirow[t]{5}{*}{ Dry Corridor } & Central & 40 & 15 & 3 & 1 \\
\hline & Esquipulas & 50 & 20 & 4 & \\
\hline & Jocotán & 30 & 15 & 6 & 3 \\
\hline & Terminal & 80 & 20 & 4 & \\
\hline & Zacapa & 50 & 25 & 5 & \\
\hline Total & & 715 & 265 & 54 & 14 \\
\hline
\end{tabular}

of them, taking them around 30-60 min to arrive. However, vendors from remote communities reported deficient infrastructure and limited access to transportation, which makes it difficult to access the market. In Guatemala City, a similar situation for chaya supply was observed, except that some vendors in smaller markets (Central and Palmita) were found to source chaya from La Terminal, a large wholesale market which is an important hub for agricultural products coming from across Guatemala. Other leafy vegetables generally had a similar value chain pathway as chaya, although with more links to large wholesale markets.

Due to limited demand in Guatemala City, vendors sell chaya mostly on request at higher prices. They reported selling a mean 3 bundles/week at a price of $0.6 \mathrm{USD} / \mathrm{bundle}$ (exchange rate at the time of study: 1 USD =7.33 Quetzal/GTQ). In the other sites, sales volumes were generally higher, but prices lower. In Petén, vendors sold a mean 10 bundles/week at a price of $0.45 \mathrm{USD} / \mathrm{bundle}$. In Chiquimula sales volumes were more variable, ranging from 1 bundle/week in the Central market to 24 bundles/week in Jocotán, with mean prices of 0.22$0.41 \mathrm{USD} /$ bundle. With these rates, we estimated that a vendor could make a mean of 9 USD per month from chaya sales in Guatemala City, 22 USD in Petén, and 12 USD in Chiquimula, with a mean rate of return at $41 \%, 26 \%$, and $9 \%$, respectively (ESM, Appendix 4). Although chaya sales only represent a mean $1.5 \%$ of vendors' gross income from vegetable sales, they contribute to covering production and transaction costs.
Vendors interviewed were selling a total of 25 species of leafy vegetables and herbs, of which the most important, based on their demand, included chipilín (Crotalaria longirostrata Hook. \& Arn.), black nightshade (Solanum americanum Mill. and S. nigrescens $\mathrm{M}$. Martens \& Galeotti), chard, spinach, watercress (Nasturtium officinale R.Br.), leaf amaranth (Amaranthus sp.), lettuce (Lactuca sativa L.), squash leaves (Cucurbita sp.), coriander (Coriandrum sativum L.), parsley (Petroselinum crispum Mill. Fuss), and spearmint (Mentha spicata L.; ESM, Appendix 5). Prices of these leafy vegetables ranged from $0.14-1.23 \mathrm{USD} /$ bundle over the year, noting that their bundles were similar in size and weight as chaya's. In Guatemala City, the price of chaya was one of the highest of all leafy vegetables on offer, only surpassed by spinach (Fig. 4). By contrast, in Chiquimula, chaya's price was the lowest compared to other leafy vegetables; while in Petén it was mid-range. Vendors explained that the prices of edible leaves, including chaya, tend to be higher by $0.14-0.27$ USD/bundle in the summer (December-May) as compared to the winter or rainy season (June-November) because production is lower, access to water is limited, and only people with access to irrigation produce enough to sell.

Low consumer demand was a reason mentioned by $88 \%$ of all the vendors interviewed for not selling chaya and preferring to trade other vegetables instead. Some vendors observed that people have lost the habit of consuming chaya and are not aware of its nutritional and medicinal qualities. Another reason for low demand for chaya in Petén and 


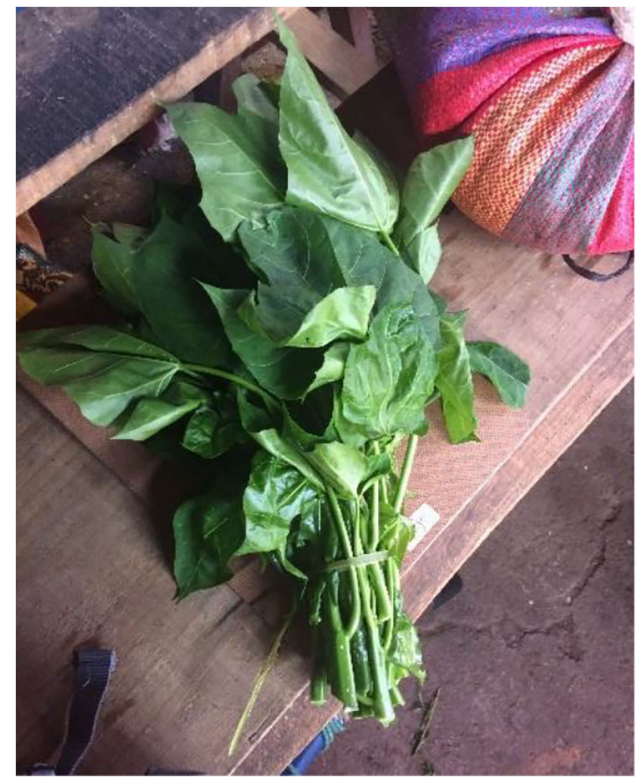

Fig. 3. Chaya bundles found in the focal markets

Chiquimula was the fact that it is grown in many households' homegardens, and thus people do not need to purchase it from the market. In these areas, around a third of vendors also expressed that there is a stigma on chaya as "food of the poor" that reduces demand and makes them embarrassed to sell it. Around $75 \%$ of vendors in Guatemala City who do not sell chaya and $60 \%$ of those in Petén and the Dry Corridor expressed their willingness to start

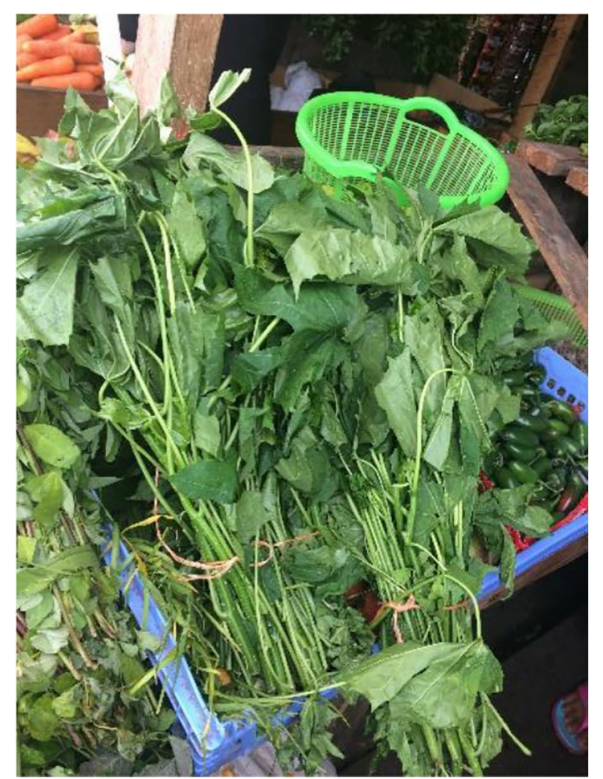

selling it, provided that a high demand and good sale price were in place, which would be enough incentive to produce or procure it.

In contrast to the situation seen in Guatemala, chaya vendors were easily found in the selected markets in Merida, Mexico. These vendors sold the leaves either by weight or in plastic bags each containing 20-30 leaves. The quantity of chaya sold, as well as the frequency of the sales in the

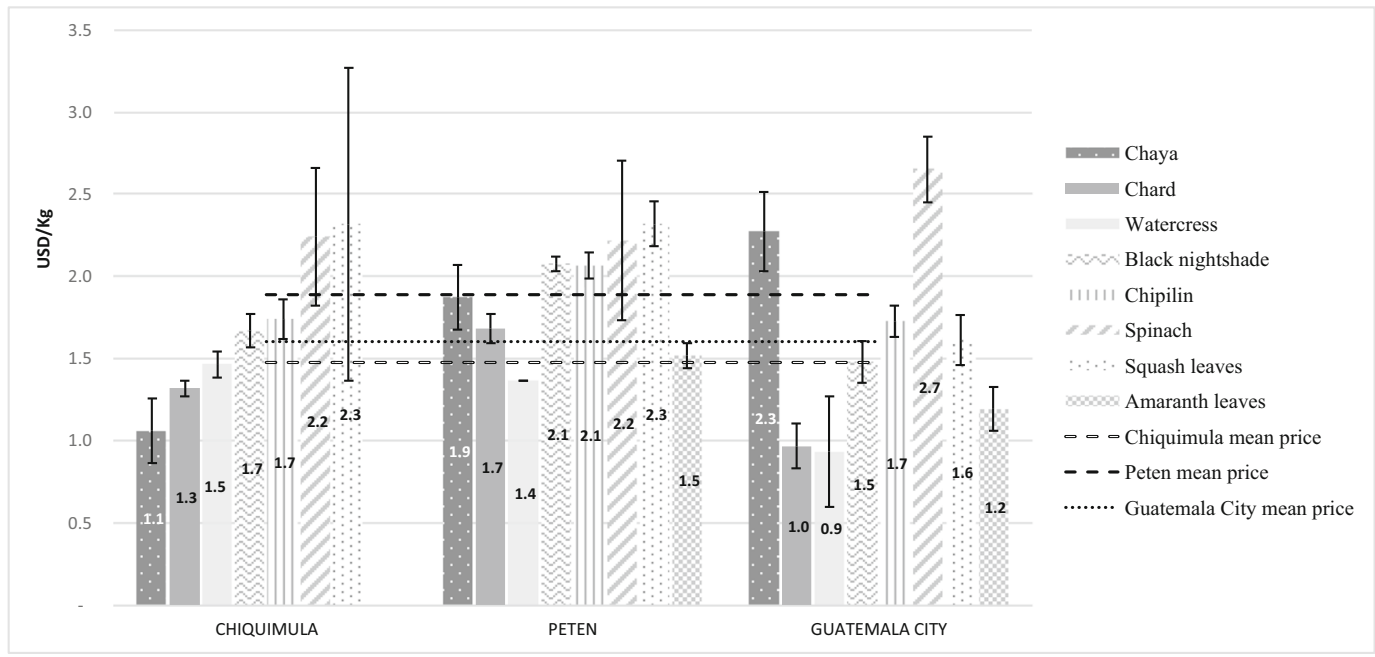

Fig. 4. Comparison of mean sales prices between chaya and commonly consumed leafy vegetables in focal markets 
markets visited, was higher than that observed in Guatemala. Chaya was usually sold every day at prices that ranged from $1.5-3.5 \mathrm{USD} / \mathrm{kg}$. In the urban markets visited, a vendor reported selling a mean $80 \mathrm{~kg}$ of chaya per week, while in the rural market a vendor sold around $27.5 \mathrm{~kg} /$ week. Vendors interviewed stated that demand for chaya is higher than for other leafy vegetables, such as spinach and lettuce, because of its importance in Maya culture and traditional gastronomy. For instance, chaya sales double during the week of Easter because it is a key ingredient of typical dishes consumed during this holiday. Chaya was also easily found in many restaurants, food stores, and supermarkets (e.g., Walmart) in Merida, suggesting that this crop is much more popular here than in Guatemala. Respondents moreover highlighted that is customary for houses in Merida to have at least one chaya plant in the homegarden.

\section{CONSUMERS Surveys}

Among the consumers interviewed in the markets, $20 \%$ in Guatemala City stated that they knew about chaya, versus $100 \%$ in Petén and $70 \%$ in the Dry Corridor. The majority (75\%) of those who knew chaya consumed it occasionally. In Guatemala City, only one of the 10 respondents consumed chaya, consumption that was motivated by knowledge of its nutritional value and availability in the homegarden.

More than half $(60 \%)$ the consumers in Petén and $10 \%$ in the Dry Corridor consumed chaya out of custom as they grew up eating it at home, while its nutritional and/or medicinal values were a primary motivation for $40 \%$ and $90 \%$ of them to consume chaya, respectively. Across all sites, a family of six members consumed a mean two bundles of chaya per week, which they procured from their homegarden, neighbors, or market. When not available at home, consumers in Petén estimated to buy 1-2 bundles/week, while those in the Dry Corridor bought 2-3 bundles/week. Besides chaya, consumers reported purchasing a mean of 7 bundles/ month of other edible leaves, such as black nightshade, chipilín, spinach, chard, and watercress to use in soups, salads, rice, with eggs and tamales (steamed maize dough wrapped in maize husk).

Overall, $60 \%$ of chaya consumers said they would like to increase their consumption, but they noted that its availability in markets is unreliable. Forty percent of chaya consumers were not interested in increasing their intake because they already consume enough; and also, interviewees in Chiquimula stated that their children prefer the taste of chipilín or black nightshade over chaya. Of the consumers in Guatemala City and the Dry Corridor that never heard about chaya, almost all (92\%) were interested to try it because of its nutritional and medicinal properties that were explained during the interviews.

\section{Restaurant Surveys}

There are small restaurants known as "Comedores" located in the focal markets in Guatemala City, Petén, and the Dry Corridor. Only one of the 14 Comedores found in the visited markets reported using chaya as an ingredient in one of its dishes. This restaurant was located in Zacapa market, where a chaya soup is served for 0.68 USD when clients request it in advance, which tends to happen around twice a month. According to owners of the Comedores interviewed in Petén, Chiquimula, and Zacapa, most of their clients come from rural communities where they usually eat traditional vegetables like chaya; thus they prefer eating something different when visiting the market. The most popular foods offered in these restaurants include fried chicken, rice, beans, and tortillas (thin flatbread, made from ground maize cooked in limewater).

In Petén, we found a restaurant named "La Chaya," where a diversity of dishes with chaya are offered. The restaurant's mission, according to its owner, is to contribute to safeguarding the country's food and Maya culture, and make its gastronomy better known and appreciated. This unique restaurant targets tourists and affluent consumers, offering dishes ranging from chaya tamales to more elaborate recipes (e.g., omelets, pasta) that cannot be found elsewhere in Petén. We were not able to find any other restaurant in the focal sites that includes chaya in its menus.

\section{Processing Industry Surveys}

The expert and internet surveys revealed that a few private companies are processing and selling nutraceutical products based on chaya (ESM, Appendix 6). We were able to interview the owners of four of these companies: Eurotropic, Sanue, Chaya Herbal, and Chaya Trading. In their marketing campaigns, these companies advertise chaya for its nutritional and health benefits, including preventing and treating obesity, anemia, kidney 
disease, and diabetes. Most of these benefits are known from anecdotal information, and at least the last three have been supported by clinical trials with mice (Oladeinde et al. 2007). These companies have been selling chaya products for more than five years and according to them, they are gaining good acceptance, even though we were not able to have access to their sales volumes.

Eurotropic is the only Guatemalan-based company among those identified. It sells chaya flour and capsules on a small-scale but at high prices (27-34 USD/package) in Guatemala and occasionally in the USA and Canada. An important challenge this company faces is the limited demand as a result of consumers' low awareness about chaya and its multiple benefits. However, the owner's connections with traders and the promotion of the products in international markets and agricultural fairs are key advantages for the company. We located a health food store in Antigua (Guatemala) that occasionally sells Eurotropic's products. No other sale points were identified that carried products made from chaya in the sites surveyed through our study.

\section{Producer Surveys}

To explore the current use and future prospects of chaya at the community level, 20 chaya producers in Petén and Chiquimula were interviewed from communities that produce, consume, and supply chaya to the focal markets. The producers were selected for the interview following a convenience sampling approach. Most of the chaya producers interviewed were women (70\%), and all spoke Spanish. Their primary economic activity was small-scale agriculture. Their main crops were maize and beans that were grown for subsistence and income, complemented by production of leafy vegetables, fruits, tubers, and flowers. In both departments, the whole family participates in chaya production and marketing activities, but women tend to be more engaged in its cultivation and deciding how to use the production.

All the producers interviewed in Petén and Chiquimula stated they grow chaya mainly for its nutritional and medicinal benefits, especially for fighting anemia and stimulating lactation. Moreover, in Petén $60 \%$ of the respondents added that they continue producing chaya out of habit. Most interviewees in Petén (40\%) and Chiquimula (73\%) appreciated that chaya grows easily, requiring few inputs and minimal care. The following comment by a producer in Chiquimula stresses this concept very well: "Chaya grows alone, it does not need so much care, basically it takes care of itself." Producers also appreciated its resistance to pests and diseases and drought tolerance; as stated by one respondent: "Chaya is fierce to face drought periods." Nevertheless, heavy drought spells and limited access to water were found to reduce yields and constrain production.

Chaya production typically took place around the farmers' houses, homegardens, or agricultural plots, and varied by region and level of access to irrigation. In Petén, where rainfall is comparably higher than in Chiquimula, all interviewees reported having access to water year-round and a mean chaya production of 5 bundles/week during the year (Fig. 5). These producers stated that they mainly used chaya to make and sell tamales; and to a lesser extent for home consumption (cooked with scrambled eggs or stews). In Chiquimula, half of the producers interviewed had access to irrigation and maintained a mean production of 20 bundles/week throughout the year, of which they sold half in local markets. By contrast, households with more limited access to water gathered 3-5 bundles/week, which they used for consumption, mostly in soups and pinol (toasted maize flour mixed with water). In both sites, farmers also shared some of their chaya within their social networks and used it to feed their animals. All the families in Petén reported producing the Estrella variety because of its higher productivity, better taste, and greater softness when cooked compared to Mansa. Conversely, in Chiquimula, the predominant variety produced out of custom was Mansa, although some chaya Estrella plants were observed during our field work.

Most producers in Petén (80\%) and Chiquimula (67\%) stated that chaya is among the most important leafy vegetables they produced. However, $75 \%$ of them prefer to consume chipilín and/or black nightshade, mostly out of habit. The production of these other vegetables is similar to chaya during winter, whereas in summer, only chaya can be harvested, since it has lower water requirements. According to $33 \%$ of the respondents in Chiquimula and $80 \%$ in Petén, increasingly people in their communities, especially younger generations, are opposed to eating or selling chaya because it is perceived as "food of the poor." This phrase was also associated by respondents to other leafy vegetables (e.g., amaranth leaves, chipilín, and black nightshade). Furthermore, a few respondents stated that some people do not consume chaya because they believe it is poisonous. Lastly, some 


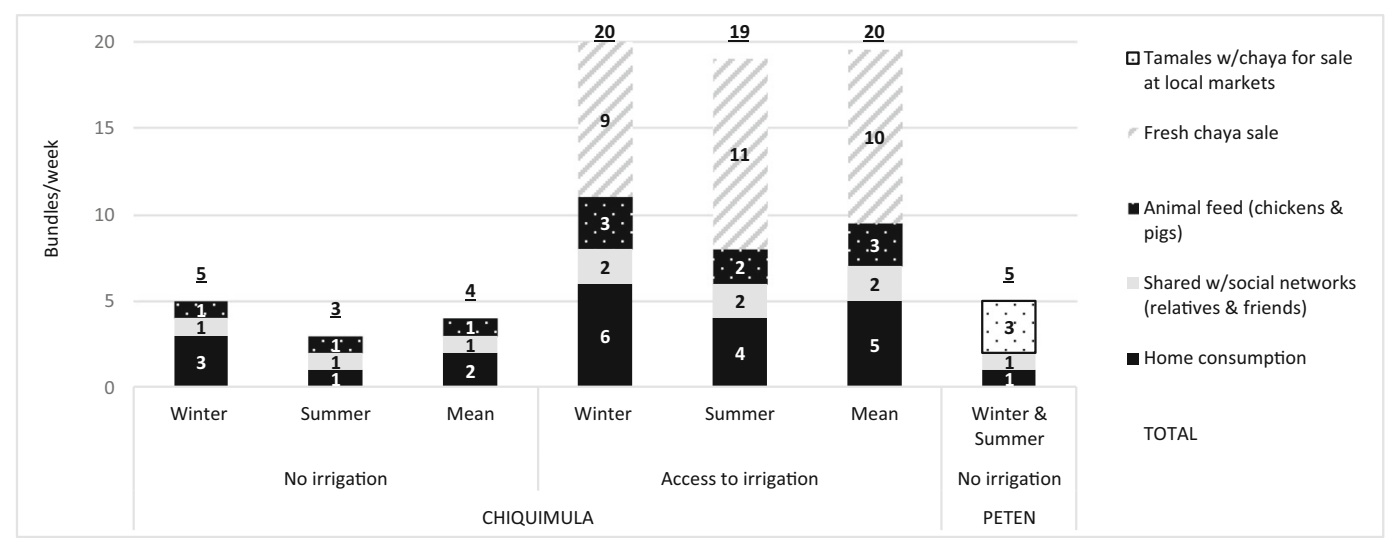

Fig. 5. Weekly mean production and uses of chaya, by season, access to irrigation, and site

interviewees in Chiquimula felt that the recipes used for chaya were not very attractive or well appreciated by children.

\section{RESEARCH AND INTERVENTIONS}

We identified and interviewed 21 organizations that work with chaya in 17 of the 22 departments in Guatemala (ESM, Appendix 7). Efforts of these institutions focus on research activities (nutritional, chemical, botanical, and agronomic), raising awareness of chaya's benefits, promotion of its production (establishment of home, school, and/or communities gardens), and consumption (workshops, recipes, and school lunches). Of these, for the last five years a couple of institutions from the private sector (e.g., universities and small businesses) and donor agencies have been assisting small-scale activities regarding marketing, processing, and increasing demand for chaya. Some of these activities include development of recipes, sharing food samples in markets, and disseminating information through videos and flyers. However, most of these organizations work independently.

\section{Discussion}

Considering the perspectives of producers, vendors, and consumers, this study has pointed to lack of demand as a primary factor restraining chaya marketing in the focal sites. Low demand is related to low awareness of the crop in Guatemala City, and consumer perceptions in Petén and the Dry Corridor. Highest levels of cultivation and consumption of chaya occur in the center of origin in the Yucatan peninsula (Mexico and Petén) and in this region, all actors interviewed knew about the crop (Ross-Ibarra 2003). By contrast, few vendors and consumers knew about chaya in Guatemala City, which is situated at the altitudinal limit for its cultivation, where it may have never featured strongly in local culinary traditions (Caceres et al. 2015). An intermediate awareness was found in the Dry Corridor, which is consistent with lower levels of cultivation in this region compared to the Yucatan peninsula (Azurdia 2016).

Although consumers knew about chaya in Petén and the Dry Corridor, this did not translate to market demand because the crop was available in homegardens and was perceived by some as "food of the poor." This perception of chaya is rooted in a legacy of discrimination against indigenous peoples in Guatemala, and other factors that contribute to shifting food culture away from traditional crops, such as urbanization, expanding markets, changing socio-economic conditions, and environmental degradation (Cristancho and Vining 2009; Ford et al. 2017). Experts interviewed highlighted that while people still have access to native plants, the culture of consuming them is slowing disappearing and reaching levels of complete extinction in some regions of Guatemala. Similar views of "food of the poor" have restrained demand for nutritious traditional crops in other parts of the world (e.g., quinoa: Andrews 2017; African leafy vegetables: Maseko et al. 2017). However, this impression was not found in the study sites in Mexico, where chaya was instead reported to be a source of pride, and its strong connection with indigenous culture 
determined its very survival and popularity. More widespread use of chaya in Mexico as compared to Guatemala was also highlighted by Cifuentes et al. (2010), while the precise reasons for this difference merits additional investigation.

Our results suggest that consumers in Guatemala may not recognize chaya as a vegetable for regular consumption but as a medicinal crop, which, it was noted, could be limiting its demand. More consumers in Petén and the Dry Corridor were motivated to use chaya for its medicinal values than for its nutritional values. The medicinal effects of chaya were also primary features promoted by the processing industry. The use of chaya as medicine can be similar to its consumption as a vegetable (e.g., eating boiled leaves), but the leaves or other parts (e.g., roots, sap) may also be consumed as teas, infusions, or shakes, or applied externally (Ross-Ibarra and Molina-Cruz 2002). Emphasis on the medicinal role of chaya made by consumers in this study contrast with observations by Ross-Ibarra and Molina-Cruz (2002) in Mexico, where the use of chaya as food was more prominent. Furthermore, observations by some respondents that chaya is poisonous also hinder the demand for this crop as a vegetable and highlight a lack of awareness about processing methods that render this crop safe for consumption.

A more habitual use and preference for black nightshade and chipilín over chaya were noted in interviews across the sites. Like chaya, these crops have also been used since pre-Colombian times in Guatemala (Azurdia 2016; Cagnato 2018). Chipilín is likely native to Mesoamerica (Azurdia 2016), while black nightshades $S$. americanum and $S$. nigrescens are wide-ranging species of the Americas (Knapp et al. 2019). The reason consumers favor these crops over chaya is not clear from the interviews, since they were also regarded as food of the poor, both are used as medicine, and black nightshade can also be toxic, needing to be boiled for safe consumption (Caceres and Cruz 2019; Jagatheeswari et al. 2013; Morton 1994). The wider altitudinal ranges of chipilín and black nightshade could explain why these crops are used more often in Guatemala City, since chaya can only grow in lowlands (i.e., up to 1500 masl; Caceres et al. 2015). These species are also generally more available and accessible as compared to chaya because they grow spontaneously in cultivated fields and have faster production of edible leaves (Azurdia 2016; Caceres et al. 2015; Mera-Ovando et al. 2011).
Agronomic constraints did not stand out as a major limiting factor for chaya. Producers described its cultivation to be easy, requiring few inputs and generating a harvest even under challenging climate conditions, which agrees with observations by other authors (NRC 1979; Peregrine 1983; Ross-Ibarra and Molina-Cruz 2002). Although chaya is tolerant to drought, our results suggest that water availability is a limitation for producers without irrigation in the Dry Corridor, thus restraining commercial production to the rainy season. Nevertheless, commercialization constraints seem to be a more critical bottleneck for market integration of chaya. The few chaya vendors that were encountered in the markets faced high transaction costs that prevented them from visiting markets frequently and selecting more profitable ones, a situation due to the fact that they are living in remote areas, distant from each other, and operating individually. This situation affects numerous crops grown in remote areas, where the transaction costs of bringing the products to market can be unrealistic (Gruère et al. 2008; Van Looy et al. 2008). Perishability did not stand out in the interviews as a constraint for marketing chaya, but other authors have determined it to be a key factor limiting wider supply and marketability-a condition that can be overcome by dehydrating the leaves (Caceres et al. 2015).

As this study focused only on three sites in Guatemala, it is possible that chaya is marketed to a greater extent in other parts of the country and, while we aimed to be thorough with our surveys, some important actors may have been missed. Focal markets were also only surveyed once, which could mean that seasonal fluctuations in the number of vendors and prices were not documented. On the other hand, actors interviewed reported that prices and quantities of chaya sold vary only minimally during the year. With these methodological limitations in mind, we are confident based on the literature review and interviews with experts that our results provide an accurate picture of current levels of chaya marketing in the target sites and also reflect the general case of chaya marketing across Guatemala.

\section{Conclusion}

This study revealed that consumption and market availability of chaya in the focal sites is irregular and insubstantial, confirming observations by Azurdia (2016) and Caceres et al. (2015). The value chain 
of chaya was found to be short and composed primarily of production, basic processing (if any), marketing (insignificant), and consumption (decreasing). A limited presence of chaya in restaurants and other retail points was also documented. As is found for many neglected and underutilized species around the world (Padulosi et al. 2015, 2019), bottlenecks were detected across the value chain, which hinder integration of chaya in markets. Lack of demand stood out as the primary limiting factor for chaya marketing, while commercialization constraints such as high transaction costs, weak value chain organization, and poor profitability are other critical bottlenecks.

Strengthening market integration of chaya can be strategic to enable its benefits to reach the fastgrowing urban population of Guatemala, for which agricultural value chains play a fundamental role in making food available (Lowitt et al. 2015). Because of its nutritious leaves and easy cultivation under low input conditions, chaya could play an important role in sustainably enhancing vegetable supply in Guatemala, a country where the majority of its citizens $(80 \%)$ currently do not meet the recommended daily vegetable intake (Afshin et al. 2019). The lower price of chaya compared to other leafy vegetables presents an opportunity for low-income consumers to affordably increase their vegetable consumption (Drewnowski 2010). At half the price of spinach in Chiquimula, chaya provides eight times more vitamin $\mathrm{C}$, four times more calcium, and two times more protein.

This research has provided a better understanding of the chaya value chain in Guatemala, which can guide sustainable development of this crop. The presence of companies marketing chaya as nutraceutical products, and the success of the chaya-specialized restaurant serving tourists in Petén, suggest that there are more profitable markets that could be accessed by chaya producers with improved organization and marketing strategies. Involving the gastronomy sector could play a strategic role in raising awareness about chaya and help to better portray this crop as a key component of Guatemala's ancient food culture ("Mayan spinach") and its value as a highly nutritious and modern "superfood." Lastly, it is vital to encourage the establishment of collaborative alliances among different organizations that work with chaya, as a key move to avoid duplication of efforts and foster synergy in strategic activities.

\section{Acknowledgments}

We would like to thank all the vendors, consumers, producers, and experts who participated in this study. Special thanks to Rolando Cifuentes and Silvana Maselli. This research was carried out in the framework of the project "Linking Agro biodiversity Value Chains Climate Adaptation and Nutrition: Empowering the Poor to Manage Risk," with funding from the European Commission and the International Fund for Agricultural Development (Grant 2000000978) and the CGIAR Research Programmes on Agriculture for Nutrition and Health and Climate Change, Agriculture and Food Security.

Open Access This article is licensed under a Creative Commons Attribution 4.0 International License, which permits use, sharing, adaptation, distribution and reproduction in any medium or format, as long as you give appropriate credit to the original author(s) and the source, provide a link to the Creative Commons licence, and indicate if changes were made. The images or other third party material in this article are included in the article's Creative Commons licence, unless indicated otherwise in a credit line to the material. If material is not included in the article's Creative Commons licence and your intended use is not permitted by statutory regulation or exceeds the permitted use, you will need to obtain permission directly from the copyright holder. To view a copy of this licence, visit http://creativecommons.org/licenses/by/4.0/.

\section{Literature Cited}

Afshin, A., P. J. Sur, K. A. Fay, L. Cornaby, G. Ferrara, J. S. Salama, E. C. Mullany et al. 2019. Health effects of dietary risks in 195 countries, 1990-2017: A systematic analysis for the Global Burden of Disease Study 2017. The Lancet 393: 1958-1972.

Andrews, D. 2017. Race, status, and biodiversity: The social climbing of quinoa. Culture, Agriculture, Food and Environment 39(1): 15-24.

Azurdia, C. 2016. Plantas Mesoamericanas Subutilizadas en la Alimentación Humana. El caso de Guatemala: Una revisión del pasado hacia una solución actual. Documento técnico: 11. Guatemala: CONAP-USAC-DGI.

Baldermann, S., L. Blagojević, K. Frede, R. Klopsch, S. Neugart, A. Neumann, B. Ngwene et al. 2016. Are neglected plants the food for the 
future? Critical Reviews in Plant Sciences 35(2): 106-119.

Bandula, A., C. Jayaweera, A. De Silva, P. Oreiley, A. Karunarathne, and S. H. P. Malkanthi. 2016. Role of underutilized crop value chains in rural food and income security in Sri Lanka. Procedia Food Science 6: 267-270.

Booth, S., R. Bressani, and T. Johns. 1992. Nutrient content of selected indigenous leafy vegetables consumed by the Kekchi people of Alta Verapaz, Guatemala. Journal of Food Composition and Analysis 5(1): 25-34.

Caceres A. and S. M Cruz. 2019. Detection and validation of native plants traditionally used as medicine in Guatemala. Current Traditional Medicine 5(1): 5-30.

Caceres A., M. Cosenza, A. López, M. Mérida, and S. Cruz. 2015. Manual de Hierbas y Granos Nativos como una Opción Agrícola, Nutricional y Comercial en Guatemala. Proyecto FODECYT 05-2013. Guatemala.

Cagnato, C. 2018. Shedding light on the nightshades (Solanaceae) used by the ancient Maya: A review of existing data, and new archaeobotanical (macro-and microbotanical) evidence from archeological sites in Guatemala. Economic Botany 72(2): 180-195.

Cifuentes, R., E. Poll, R. Bressani, and S. Yurrita. 2010. Caracterización botánica, molecular, agronómica y química de los cultivares de Chaya (Cnidoscolus aconitifolius) de Guatemala. Revista Universidad del Valle de Guatemala 21: 34-49.

Cristancho, S. and J. Vining. 2009. Perceived intergenerational differences in the transmission of traditional ecological knowledge (TEK) in two indigenous groups from Colombia and Guatemala. Culture and Psychology 15(2): 229-254.

Drewnowski, A. 2010. The Nutrient Rich Foods Index helps to identify healthy, affordable foods. American Journal of Clinical Nutrition 91(4): 1095S-1101S.

FAO. 2018. World food and agriculture-Statistical Pocketbook 2018. Rome: FAO.

FAO, IFAD, UNICEF, WFP, and WHO. 2017. The state of food security and nutrition in the world 2017. Building Resilience for Peace and Food Security. Rome: FAO.

FDA (Food and Drug Administration). 2016. Food labeling: Revision of the nutrition and supplement facts labels. Federal Register 81: Docket FDA-2012-N-1210.

Ferraz, C. A., A. P. Oliveira, C. Souza-Araújo, L. F. da Silva-Oliveira, L. Picot, L. Araújo-Rolim, P. J.
Rolim-Neto et al. 2018. Phytochemical and pharmacological aspects of Cnidoscolus pohl species: A systematic review. Phytomedicine 50: 137-147.

Ferris, S. 2012. A guide to Rapid Market Appraisal (RMA) for agricultural products. Cali, Colombia: CIAT, CRS and Helvetas.

Ford, N. D., R. Martorell, M. Ramirez-Zea, and A. D. Stein. 2017. The nutrition transition in rural Guatemala: 12-year changes in diet of adults. FASEB Journal 31: 147-3.

González-Laredo, R., M. F. De La Hoya, M. Quintero-Ramos, and J. Karchesy. 2003. Flavonoid and cyanogenic contents of chaya (spinach tree). Plant Foods for Human Nutrition 58(3): $1-8$.

Grant, P. 2015. State of the World's Minorities and Indigenous Peoples 2015: Events of 2014, Focus on Cities. London: MRG.

Gruère, G. P., A. Giuliani, and M. Smale. 2008. Marketing underutilized plant species for the benefit of the poor: A conceptual framework. In: Agrobiodiversity conservation and economic development, eds. A. Kontoleon, U. Pasqual, and M. Smale, 73-87. Abingdon: Routledge.

Holtzman, J. S. 2003. Rapid appraisals of commodity sub-sectors. Bethesda: Abt Associates, Inc.

Hunter, D., T. Borelli, D. M. Beltrame, C. N. Oliveira, L. Coradin, V. W. Wasike, L. Wasilwa et al. 2019. The potential of neglected and underutilized species for improving diets and nutrition. Planta: 1-21.

Hyde, K. F. 2000. Recognizing deductive process in qualitative research. Qualitative Market Research. International Journal 3(2): 82-89.

IICA (Instituto Interamericano de Cooperación para la agricultura). 2015. Diagnóstico del marco político, institucional y programático de la agricultura familiar en Guatemala. Informe de consultoría:30. Guatemala.

INE (Instituto Nacional de Estadística). 2004. IV Censo Nacional Agropecuario 2003. Guatemala - 2011. Mapas de pobreza Rural en Guatemala 2011. Guatemala: Unidad de Pobreza, Género y Equidad del Banco Mundial. Latinoamérica y el Caribe.

- 2014. Encuesta Nacional de Condiciones de Vida 2013. Guatemala.

Jagatheeswari, D., T. Bharathi, and H. Sheik Jahabar Ali. 2013. Black nightshade (Solanum nigrum L.)-An updated overview. International Journal of Pharmaceutical and Biological Archive 4(2): 288-295. 
Kaplinsky, R. and M. Morris. 2000. A handbook for value chain research. University of Sussex, Institute of Development Studies (113).

Knapp, S., G. E. Barboza, L. Bohs, and T. Särkinen. 2019. A revision of the Morelloid Clade of Solanum L. (Solanaceae) in North and Central America and the Caribbean. PhytoKeys 123: 1144.

Kumar, A., M. Or-Rashid, O. Alzahal, and B. W. Mcbride. 2011. Fatty acid profile of chaya (Cnidoscolus aconitifolius) leaves and fodder. Indian Journal of Animal Sciences 81(8): 95-100.

Kuti, J. O. and E. S. Torres. 1996. Potential nutritional and health benefits of tree spinach. Progress in New Crops 13(5): 516-520.

Leung, W. T. W. and M. Flores. 1961. Food composition table for use in Latin America. Bethesda: INCAP and ICNND.

Lowitt, K., G. M. Hickey, W. Ganpat, and L. Phillip. 2015. Linking communities of practice with value chain development in smallholder farming systems. World Development 74: 363-373.

MAGA (Ministerio de Agricultura, Ganadería y Alimentación). 2015. Plan Operativo Anual 2016 y Multianual 2016-2018. Guatemala.

- 2016. Informe Situación del frijol: Junio, 2016. Guatemala: Dirección de Planeamiento.

Maseko, I., T. Mabhaudhi, S. Tesfay, H. Araya, M. Fezzehazion, and C. Plooy. 2017. African leafy vegetables: A review of status, production and utilization in South Africa. Sustainability 10(1): 16.

Mera-Ovando, L. M., D. Castro-Lara, and R. ByeBoettler. 2011. Especies vegetales poco valoradas: Una alternativa para la seguridad alimentaria. México: UNAM - SNICS SINAREFI.

Molina-Cruz, A. and R.Cifuentes. 2001. Evaluación de cuatro selecciones de chaya (Cnidoscolus aconitifolius; Euphorbiaceae) y dos niveles de defoliación en cuatro regiones de Guatemala, y aceptabilidad de sus hojas y cogollos en humanos. Proyecto FODECYT 45-99. Guatemala: SENACYT-CONCYT.

Molina-Cruz, A., L. Curley, and R. Bressani. 1997. Redescubriendo el valor nutritivo de las hojas de chaya (Cnidoscolus aconitifolius; Euphorbiaceae). Universidad del Valle de Guatemala 3: 1-4.

Morton, J. F. 1994. Pito (Erythrina berteroana) and chipilín (Crotalaria longirostrata), (Fabaceae), two soporific vegetables of Central America. Economic Botany 48(2): 130-138.
MSPAS (Ministerio de Salud Pública y Asistencia Social), INE, and ICF International. 2017. VI Encuesta Nacional de Salud Materno Infantil 2014-2015. Guatemala: SEGEPLAN.

Narciso, R., D. Estrada, P. Escobar, and M. Reyes. 2013. Caracterización estadística: República de Guatemala 2012. Guatemala: INE.

Neufeld, L., S. Hernández, and A. Fernández. 2006. Hacia la erradicación de la desnutrición infantil en Centroamérica y República Dominicana. Desnutrición crónica en Centroamérica e inventario de intervenciones nutricionales. Instituto Nacional de Salud Pública 2: 1-96.

NRC (National Research Council). 1979. Tropical legumes: Resources for the future. Report of an Ad Hoc Panel of the Advisory Committee on Technology Innovation, Board on Science and Technology for International Development, Commission on International Relations. Vol. 25. Washington, D.C.: The National Academies Press.

Oladeinde, F. O., A. M. Kinyua, A. A. Laditan, R. Michelin, J. L. Bryant, F. Denaro, J. M. Makinde et al. 2007. Effect of Cnidoscolus aconitifolius leaf extract on the blood glucose and insulin levels of inbred type 2 diabetic mice. Cellular and Molecular Biology 53(3): 34-41.

Padulosi, S., B. Mal, O. King, and E. Gotor. 2015. Minor millets as a central element for sustainably enhanced incomes, empowerment, and nutrition in rural India. Sustainability 7(7): 89048933.

Padulosi, S., D. M. Cawthorn, G. Meldrum, R. Flore, A. Halloran, and F. Mattei. 2019. Leveraging neglected and underutilized plant, fungi, and animal species for more nutrition sensitive and sustainable food systems. Reference Module in Food Science, Elsevier.

Peregrine, W. T. H. 1983. Chaya (Cnidoscolus aconitifolius) - A potential new vegetable crop for Brunei. International Journal of Pest Management 29(1): 39-41.

Porres, V. and R. Cifuentes. 2014. La chaya una planta muy nutritiva. Proyecto USDA-FFPr10. Guatemala: CEAA-Universidad del Valle de Guatemala.

Ross-Ibarra, J. 2003. Origen y domesticación de la chaya (Cnidoscolus aconitifolius Mill IM Johnst): La espinaca Maya. Estudios Mexicanos 19(2): 287-302.

Ross-Ibarra, J. and A. Molina-Cruz. 2002. The ethnobotany of chaya (Cnidoscolus aconitifolius 
ssp. aconitifolius Breckon): A nutritious Maya vegetable. Economic Botany 56(4): 350-365.

SEGEPLAN (Secretaria de Planificación y Programación). 2002. Estrategia de reducción de la pobreza: El camino de la paz. Guatemala: Ed. Mercaprint.

. 2011a. Plan de Desarrollo Departamental de Chiquimula 2011-2025. Guatemala: CODEDE.

. 2011b. Plan de Desarrollo Departamental de Zacapa. 2011-2025. Guatemala: CODEDE.
2013. Diagnóstico Territorial de Petén 2032. Guatemala: SPOT.

U.N. 2017. World Population Prospects: The 2017 Revision. New York: DESA, Population Division.

Van Looy, T., G. O. Carrero, E. Mathijs, and E. Tollens. 2008. Underutilized agroforestry food products in Amazonas (Venezuela): A market chain analysis. Agroforestry Systems 74(2): 127-141. 